\title{
PENELITIAN PENDAHULUAN KUALITAS AIR TANAH \\ DI BANJAR SUWUNG BATAN KENDAL, KELURAHAN SESETAN, KOTA DENPASAR
}

\author{
(INTRODUCTION RESEARCH GROUND WATER QUALITY \\ IN BR. SUWUNG BATAN KENDAL, SESETAN, DENPASAR CITY)
}

\author{
DESAK PUTU RISKY VA ${ }^{1}$, NI PUTU RAHAYU ARTINI ${ }^{1}$, I WAYAN TANJUNG ARYASA ${ }^{1}$ \\ ${ }^{1}$ IIK Medika Persada Bali, Jln. Tantular Barat No. 9 Renon, Denpasar
}

\begin{abstract}
Abstrak: Sumber air di daerah Br. Suwung Batan Kendal sebagian besar berasal dari sumur bor yang kemudian digunakan untuk berbagai keperluan rumah tangga. Penelitian ini bertujuan untuk mengetahui kualitas air tanah milik penduduk dan memberikan informasi awal tentang kualitas air tanah yang tinggal disekitar daerah Banjar Suwung Batan Kendal. Pemeriksaan kualitas air tanah meliputi pemeriksaan parameter fisika antara lain suhu dan TDS serta parameter kimia antara lain $\mathrm{pH}$, kesadahan, dan alkalinitas. Berdasarkan Peraturan Gubernur Bali No. 16 Tahun 2016, air tanah di wilayah Banjar Batan Kendal, Desa Suwung Kangin, Kecamatan Denpasar Selatan, Denpasar dapat digolongkan ke dalam baku mutu kelas I, yaitu air yang diperuntukkan dapat digunakan untuk bahan baku air minum, karena parameter fisika (suhu dan TDS) dan kimia ( $\mathrm{pH}$, kesadahan, dan alkalinitas) yang diuji berada di bawah ambang batas maksimum yang diijinkan, namun jika dibandingkan dengan PERMENKES RI No. 492/MENKES/PER/IV/2010 tentang Persyaratan Kualitas Air Minum, air tanah di wilayah Banjar Batan Kendal tidak layak diperuntukkan untuk air minum karena parameter fisika berupa kadar TDS (Total Dissolve Solid) telah melebihi batas maksimum yang diijinkan, yaitu $500 \mathrm{mg} / \mathrm{L}$.
\end{abstract}

Kata Kunci: alkalinitas, kesadahan, kualitas air, Suwung Batan Kedal, TDS.

Abstract: Water sources in the area Br. Suwung Batan Kendal largely derived from the wellbore which is then used for various household purposes. This study aims to determine the water quality of people's land and provide initial information on groundwater quality living near Br. Suwung Batan Kendal. Groundwater quality inspection includes examination of physical parameters include temperature and TDS and chemical parameters include pH, hardness, and alkalinity. Based on Peraturan Gubernur Bali No. 16 Tahun 2016, the groundwater in the area of Banjar Batan Kendal, Village Suwung Kangin, South Denpasar District, Denpasar can be classified into standard class I, ie water which is applied can be used as raw material for drinking water, because the physical parameters (temperature and TDS) and chemical ( $\mathrm{pH}$, hardness and alkalinity) tested were below the maximum allowed, but when compared with PERMENKES RI No. 492/MENKES/PER/IV/2010 regarding Requirements Drinking Water Quality, ground water in the Banjar Batan Kendal unfit intended for drinking water because of physical parameters such as levels of TDS (Total Dissolve Solid) has exceeded the maximum allowed, which exceeded the threshold $500 \mathrm{mg} / \mathrm{L}$.

Keywords: alkalinity, hardness, Suwung Batan Kedal, Total Dissolve Solid, water quality.

\section{PENDAHULUAN}

Air merupakan suatu kebutuhan yang tidak dapat ditinggalkan bagi kehidupan Manusia, karena air diperlukan untuk bermacam-macam kegiatan seperti minum, pertanian, industri dan perikanan. Air yang dapat diminum adalah air yang bebas dari bakteri berbahaya dan ketidakmurnian secara kimiawi. Air minum harus bersih dan jernih, tidak berbau dan tidak berwarna, dan tidak mengandung bahan tersuspensi atau kekeruhan (Adiono, 1987).
Air bersih adalah air yang digunakan untuk keperluan sehari-hari dan akan menjadi air minum setelah dimasak terlebih dahulu yang memenuhi persyaratan bagi sistem penyediaan air minum. Adapun persyaratan yang dimaksud adalah persyaratan dari segi kualitas air yang meliputi kualitas fisik, kimia, biologi dan radiologis, sehingga apabila dikonsumsi tidak menimbulkan efek samping (Ketentuan Umum Permenkes No.416/ Menkes/PER/IX/1990).

Peraturan Pemerintah No. 82 tahun 2001 tentang Pengelolaan Kualitas Air dan Pengendalian Pencemaran Air menyatakan bahwa

• email korespondensi: riskyvidika@gmail.com 
yang dimaksud dengan air adalah semua air yang terdapat pada, diatas ataupun dibawah permukaan tanah, termasuk dalam pengertian air permukaan, air tanah, air hujan, air laut yang berada di darat. Air yang masuk ke tubuh manusia baik berupa makanan dan minuman tidak menyebabkan penyakit, maka pengolahan air baik berasal dari sumber, jaringan transmisi atau distribusi adalah mutlak diperlukan untuk mencegah terjadinya kontak antara kotoran sebagai sumber penyakit dengan air yang diperlukan (Sutrisno, 2004).

Salah satu sumber baku air bersih yang biasa digunakan penduduk adalah air yang berasal dari sumur bor. Sumur bor adalah jenis sumur dengan cara pengeboran lapisan air tanah yang lebih dalam ataupun lapisan tanah yang jauh dari tanah permukaan dapat dicapai sehingga sedikit dipengaruhi kontaminasi. Umumnya air ini bebas dari pengotor mikrobiologi dan secara langsung dapat dipergunakan sebagai air minum. Air tanah ini dapat diambil dengan pompa tangan maupun pompa mesin (Depkes RI, 1985).

Pada penelitian yang telah dilakukan sebelumnya yaitu tentang uji kualitas air pada sumur gali dan sumur bor seperti Analisis Kualitas Air Sumur Sekitar Wilayah Tempat Pembuangan Akhir Sampah (Studi Kasus di TPA Galuga Cibungbulang Bogor), Kajian Kualitas Air dan Penggunaan Sumur Gali Oleh Masyarakat di Sekitar Sungai Kaliyasa Kabupaten Cilacap dan Analisis Kualitas Air Tanah Masyarakat Di Sekitar Tempat Pembuangan Akhir (TPA) Sampah Kelurahan Sumur Batu Bantar Gebang Bekasi Tahun 2013 diperoleh hasil yang kurang memuaskan dan kualitasnya tidak sesuai dengan baku mutu yang sudah ditetapkan dari pemerintah. Berdasarkan beberapa penelitian tersebut dan terkait dengan pemanfaatannya sebagai air baku air minum sehingga menimbulkan ide untuk mengadakan penelitian yang sama pada sumur bor atau sumur gali didaerah kami yaitu daerah Banjar Suwung Batan Kendal, Kecamatan Denpasar Selatan. Sebagai parameter awal yang akan diuji adalah TDS, pH, suhu, alkalinitas dan kesadahan.

\section{METODE PENELITIAN}

Sampel penelitian. Sampel penelitian yang digunakan adalah sampel air tanah yang diambil di tiga titik lokasi, yaitu bagian utara, tengah dan selatan di wilayah Banjar Batan Kendal, Desa Suwung Kangin, Kecamatan Denpasar Selatan, Denpasar, Bali.
Peralatan dan Bahan Kimia. Bahan-bahan kimia yang digunakan pada penelitian ini adalah bahan kimia untuk uji kesadahan, yaitu larutan baku ZnSO4, buffer salmiak, indikator EBT dan larutan baku sekunder EDTA. Bahan kimia untuk pengujian alkalinitas yaitu larutan baku asam oksalat, indikator pp dan larutan baku sekunder $\mathrm{H}_{2} \mathrm{SO}_{4}$. Peralatan yang digunakan pada penelitian ini terdiri dari peralatan gelas, yaitu seperangkat alat titrasi, gelas ukur $100 \mathrm{~mL}$, corong glass, beaker glass, erlenmeyer $250 \mathrm{~mL}$, ball filler, pipet tetes, pipet volume $10 \mathrm{~mL}$, dan oven.

\section{Prosedur Kerja}

Pengambilan sampel air. Sampel air tanah diambil dari sumur milik penduduk di Banjar Batan Kendal, Desa Suwung Kangin, Kecamatan Denpasar Selatan, Denpasar, Bali, lalu ditampung dalam jeringen sampai penuh dan tidak ada gelembung udaranya. Di lokasi saat pengambilan sampel dilakukan pengukuran suhu dan $\mathrm{pH}$. Sampel air kemudian dibawa ke laboratorium untuk pengujian.

Analisis sifat fisika. Pengujian sifat fisika meliputi pemeriksaan parameter suhu dan TDS (Total Dissolve Solid). TDS sampel air diuji dengan metode gravimetri. Sampel air diaduk dengan sempurna, lalu disaring dengan kertas saring.

\section{Analisis sifat kimia}

Pengukuran pH. Pengukuran $\mathrm{pH}$ sampel air diawali dengan melakukan kalibrasi pada $\mathrm{pH}$ meter. Disiapkan larutan buffer ber-pH asam (buffer $\mathrm{pH} 4,0$ ), $\mathrm{pH}$ netral (buffer $\mathrm{pH} 7,0$ ), dan $\mathrm{pH}$ basa (buffer $\mathrm{pH}$ 10,0). Kemudian dilakukan pengukuran pada sampel air.

Alkalinitas. Dipipet sebanyak $10 \mathrm{~mL}$ sampel air lalu dimasukkan ke dalam Erlenmeyer $250 \mathrm{~mL}$, lalu ditambahkan dua sampai tiga tetes indicator fenolftalein. Larutan kemuadian dititrasi dengan asam sulfat $0,1 \mathrm{~N}$. Titrasi dihentikan sampai terjadi perubahan warna dari bening menjadi merah muda. Dilakukan pengulangan sampai dua kali terhadap percobaan diatas sampai diperoleh hasil yang konstan. Dihitung alkalinitas total air dalam satuan $\mathrm{g} / 100 \mathrm{~mL}$.

Kesadahan. Dipipet sebanyak $10 \mathrm{~mL}$ sampel air dengan menggunakan pipet volume, kemudian ditambahi satu sampai dua tetes buffer salmiak dan tiga tetes indicator EBT. Larutan tersebut kemudian dititrasi dengan larutan EDTA hingga terjadi perubahan warna dari merah anggur 
menjadi biru. Dibaca volume larutan EDTA yang digunakan. Diulangi percobaan tersebut sebanyak dua kali sampai diperoleh hasil yang konstan. Dihitung kesadahan total air sebagai $\mathrm{mg} \mathrm{CaCO}_{3}$ per liter sampel.

\section{HASIL DAN PEMBAHASAN}

Berdasarkan hasil penentuan titik sampling air tanah di wilayah Banjar Batan Kendal, Desa Suwung Kangin, Kecamatan Denpasar Selatan, Denpasar, Bali, ditetapkan tiga titik sampling, yaitu wilayah utara, tengah, dan timur. Dimana lokasi tersebut dipilih berdasarkan beberapa kriteria, yaitu air tanah yang bersumber dari perumahan, air tanah yang diambil di tempat usaha pencucian motor, dan air tanah yang diambil di home stay. Waktu pengambilan air sumur dilakukan di siang hari dan cuaca cerah.

\section{Hasil Pemantauan}

Analisis kualitas air tanah di wilayah Banjar Batan Kendal, Desa Suwung Kangin, Kecamatan Denpasar Selatan, Denpasar, Bali meliputi pemeriksaan parameter fisika dan kimia. Hasil analisis dibandingkan dengan baku mutu air kelas I berdasarkan Peraturan Gubernur Bali No. 16 Tahun 2016. Hasil analisis disajikan pada Tabel. Sifat fisika yang diamati berupa suhu dan TDS (Total Dissolve Solid). Sedangkan sifat kimia yang diamati berupa $\mathrm{pH}$, kesadahan, dan alkalinitas.

\section{Tabel. Hasil analisis Kualitas Air Tanah Banjar Batan Kendal, Desa Suwung Kangin, Kecamatan Denpasar Selatan, Denpasar, Bali}

\begin{tabular}{|c|c|c|c|c|c|c|}
\hline \multirow{2}{*}{ No. } & \multirow{2}{*}{ Parameter } & \multirow{2}{*}{ Satuan } & \multirow{2}{*}{$\begin{array}{c}\text { Baku } \\
\text { Mutu*) }\end{array}$} & \multicolumn{3}{|c|}{ Hasil } \\
\hline & & & & SI & SII & SIII \\
\hline \multicolumn{7}{|c|}{ Parameter Fisika } \\
\hline 1 & Suhu & ${ }^{0} \mathrm{C}$ & Deviasi 3 & 30 & 30 & 30 \\
\hline 2 & TDS & $\mathrm{mg} / \mathrm{L}$ & 1000 & 630 & 550 & 510 \\
\hline \multicolumn{7}{|c|}{ Parameter Kimia } \\
\hline 3 & $\mathrm{pH}$ & - & $6-9$ & 8,25 & 7,97 & 8,68 \\
\hline 4 & Kesadahan & $\mathrm{mg} \mathrm{CaCO}_{3} / \mathrm{L}$ & - & 17,615 & 13,409 & 8,807 \\
\hline 5 & Alkalinitas & $\mathrm{mg} / \mathrm{L}$ & - & 12 & 16 & 40 \\
\hline \\
\hline III & $\begin{array}{l}\text { Air tanah rumah } \\
\text { Air tanah usaha } \\
\text { Air tanah home. }\end{array}$ & $\begin{array}{l}\text { ci motor } \\
a y\end{array}$ & & & & \\
\hline
\end{tabular}

\section{Hasil Pemeriksaan Parameter Fisika Analisis Suhu Air Tanah}

Hasil analisis kualitas air tanah di Banjar Batan Kendal, Desa Suwung Kangin, Kecamatan Denpasar Selatan, Denpasar, Bali yang disajikan pada Tabel di atas memenuhi kriteria baku mutu kelas I sesuai dengan Peraturan Gubernur Bali No. 16 Tahun 2016. Berdasarkan hasil pengujian parameter fisika, suhu secara keseluruhan sampel air tanah di wilayah Banjar Batan Kendal, Desa Suwung Kangin, Kecamatan Denpasar Selatan, Denpasar, Bali menunjukkan hasil yang sama, yaitu memiliki suhu $30^{\circ} \mathrm{C}$.

Kenaikan terperatur dapat disebabkan karena berkurangnya jumlah oksigen terlarut. Oksigen terlarut adalah jumlah oksigen yang diperlukan oleh mikroorganisme dalam menguraikan zat-zat organik dalam perairan. Namun, secara keseluruhan temperatur air saat pengukuran di laboratorium adalah sama.

\section{Analisis TDS (Total Dissolve Solid) Air Tanah}

Parameter fisika lain yang diuji berupa residu terlarut (TDS). TDS adalah jumlah ion Kalsium $(\mathrm{Ca})$ dan Magnesium $(\mathrm{Mg})$ di dalam air yang menyebabkan sifat kesadahan terhadap air tersebut. Air yang mempunyai tingkat kesadahan tinggi, pada alat-alat yang terbuat dari besi akan timbul kerak-kerak. Berdasarkan hasil analisis kadar TDS air tanah di Banjar Batan Kendal, Desa Suwung Kangin, Kecamatan Denpasar Selatan, Denpasar, Bali menunjukkan hasil yang beragam namun masih berada di bawah baku mutu sesuai peruntukan untuk baku mutu kelas I, yaitu air yang diperuntukkan untuk baku air minum. Ambang batas yang diijinkan untuk kadar TDS pada baku mutu air kelas I adalah $1000 \mathrm{mg} / \mathrm{L}$.

Kadar TDS tertinggi adalah $630 \mathrm{mg} / \mathrm{L}$ pada air tanah sampel SI (air tanah rumah penduduk), untuk SII (air tanah usaha cuci motor) memiliki kadar TDS $550 \mathrm{mg} / \mathrm{L}$, dan SIII (air tanah home stay) memiliki TDS $510 \mathrm{mg} / \mathrm{L}$. Kadar TDS yang lebih tinggi di lokasi sampling tersebut didukung dengan kondisi air tanah yang agak licin- 
licin bila dibilas ditangan. Kondisi air yang licin disebabkan oleh tingginya $\mathrm{pH}$ air, serta kandungan alkalinitas yang tinggi. Hal ini juga didukung dari parameter kimia berupa hasil $\mathrm{pH} 8,25$. pH yang aman sesuai dengan Peraturan Gubernur Bali No. 16 Tahun 2016 adalah 6-9, namun PERMENKES RI No. 492/MENKES/PER/IV/2010 tentang Persyaratan Kualitas Air Minum memberikan persyaratan yang lebih rendah untuk batas maksimim $\mathrm{pH}$ yaitu 6,5-8,5. Semakin tinggi $\mathrm{pH}-$ nya semakin licin air di wilayah tersebut.

Jika ditinjau berdasarkan PERMENKES RI No. 492/MENKES/PER/IV/2010 tentang Persyaratan Kualitas Air Minum, untuk batas maksimum TDS adalah $500 \mathrm{mg} / \mathrm{L}$. Berdasarkan acuan tersebut, secara keseluruhan sampel air tanah di Banjar Batan Kendal, Desa Suwung Kangin, Kecamatan Denpasar Selatan, Denpasar, Bali telah melebihi ambang batas baku mutu kualitas air minum. Sehingga bisa dikatakan bahwa air tanah yang diambil di wilayah Batan Kendal tidak dapat dimanfaatkan untuk bahan baku air minum, namun dapat diperuntukkan sebagai pembudidayaan air tawar, sarana rekreasi, peternakan, air untuk mengairi pertamanan, dan persyaratan lain sesuai dengan kegunaannya tersebut.

\section{Hasil Pemeriksaan Parameter Kimia Analisis pH Air Tanah}

Parameter kimia yang diuji pada penelitian kualitas air tanah di wilayah Banjar Batan Kendal, Desa Suwung Kangin, Kecamatan Denpasar Selatan, Denpasar, Bali adalah pH, kesadahan, dan alkalinitas. Berdasarkan ambang batas sesuai dengan Peraturan Gubernur Bali No. 16 Tahun 2016, secara keseluruhan hasil analisis parameter kimia masih normal.

Untuk hasil analisi $\mathrm{pH}$, sampel air tanah berada dalam ambang batas normal kelas I yang digunakan untuk bahan baku air minum dan atau peruntukan lain yang mempersyaratkan mutu air yang sama, yaitu pH 6-9. Namun, untuk sampel air SI dan SIII sudah mulai hati-hati dalam penggunaannya. Karena berdasarkan analisis sudah berada dalam rentang $\mathrm{pH}$ mendekati batas maksimum peruntukan air kelas I, yaitu 8,25 untuk pH SI (air tanah perumahan) dan 8,68 untuk pH SIII (air tanah home stay).

Untuk pH yang tinggi berpengaruh pada sifat fisika dari air yaitu, menyebabkan kondisi air menjadi licin bila digunakan dalam hal membilas dan menimbulkan warna kuning bila digunakan untuk mencuci pakaian. Namun, bila ditinjau dari PERMENKES RI No. 492/MENKES/PER/IV/2010 tentang Persyaratan
Kualitas Air Minum, rentang pH yang diijinkan adalah 6,5-8,5. Bila ditinjau dari peraturan tersebut, untuk sampel air SI dan SII masih berada dalam rentang batas normal $\mathrm{pH}$ yang diijinkan untuk Persyaratan Kualitas Air Minum, namun untuk sampel SIII (air tanah home stay) telah melewati batas maksimum untuk persyaratan kualitas air minum.

Hasil $\mathrm{pH}$ yang diatas batas normal diduga karena adanya kandungan ion $\mathrm{Ca}^{2+}$ dan $\mathrm{Mg}^{2+}$ yang berlebih. Hasil ini perlu dikonfirmasi dengan pemeriksaan kandungan logam pada air tanah secara spektrofotometer serapan.

\section{Analisis Kadar Kesadahan Air tanah}

Berdasarkan PERMENKES RI No. 492/MENKES/PER/IV/2010 tentang Persyaratan Kualitas Air Minum, untuk batas maksimum maksimum air yang layak minum adalah 500 mg per liter.

Hasil analisis secara keseluruhan sampel air untuk parameter kesadahan di wilayah Banjar Batan Kendal, Desa Suwung Kangin, Kecamatan Denpasar Selatan, Denpasar adalah normal. Kesadahan tertinggi adalah sampel air SI dengan nilai $17,615 \mathrm{mg} / \mathrm{L}$, disusul SII dengan 13,409 mg/ L, dan kesadahan terendah adalah sampel air SIII 8,807 $\mathrm{mg} / \mathrm{L}$. Bila dikaitkan dengan kandungan logam $\mathrm{Ca}$ dan $\mathrm{Mg}$, jumlahnya diperkirakan masih rendahnya jumlah ion $\mathrm{Ca}^{2+}$ dan $\mathrm{Mg}^{2+}$ yang terpapar dalam sampel air di wilayah tersebut.

Berdasarkan letak geografis keberadaan sumur-sumur tersebut, jauh dari batuan kapur. Selain itu, lokasi pengambilan sampel air tanah jauh dari pantai. Semakin dekat dengan bukit kapur maka kadar $\mathrm{CaCO}_{3}$ semakin besar karena kandungan utama dari kapur adalah ion $\mathrm{Ca}^{2+}$ dan $\mathrm{Mg}^{2+}$.

\section{Analisis Alkalinitas Air Tanah}

Dari hasil analisis terhadap total alkalinitas air tanah Banjar Batan Kendal, Desa Suwung Kangin, Kecamatan Denpasar Selatan, Denpasar berkisar antara 12-40 mg/L.

Kadar alkalinitas total yang diijinkan tidak boleh melebihi $1000 \mathrm{mg} / \mathrm{L}$. Apabila kadar total alkalinitasnya melampaui batas yang ditetapkan maka akan terbentuk kerak atau endapan. Kadar alkalinitas tertinggi adalah $40 \mathrm{mg} / \mathrm{L}$ pada sampel air SIII (air tanah home stay). Hasil analisis total alkalinitas berbanding terbalik dengan kesadahan. Semakin tinggi total kesadahan semakin kecil jumlah air yang diperlukan untuk menetralkan asam-asam lemah yang terdapat pada sampel air. Hasil tersebut sesuai dengan hasil analisis 
laboratorium pengujian sampel air. Sampel air SIII memiliki total kesadahan terendah, sehingga alkalinitas yang dihasilkan pun semakin besar dibandingkan dengan SI dan SII.

\section{SIMPULAN}

Berdasarkan Peraturan Gubernur Bali No. 16 Tahun 2016, air tanah di wilayah Banjar Batan Kendal, Desa Suwung Kangin, Kecamatan Denpasar Selatan, Denpasar dapat digolongkan ke dalam baku mutu kelas I, yaitu air yang diperuntukkan dapat digunakan untuk bahan baku air minum, karena parameter fisika (suhu dan TDS) dan kimia ( $\mathrm{pH}$, kesadahan, dan alkalinitas) yang diuji berada di bawah ambang batas maksimum yang diijinkan. Berdasarkan PERMENKES RI No.492/MENKES/PER/IV/2010 tentang Persyaratan Kualitas Air Minum, air tanah di wilayah Banjar Batan Kendal, Desa Suwung Kangin, Kecamatan Denpasar Selatan, Denpasar tidak layak diperuntukkan untuk air minum karena parameter fisika berupa kadar TDS (Total Dissolve Solid) telah melebihi batas maksimum yang diijinkan, yaiu melewati ambang batas $500 \mathrm{mg} / \mathrm{L}$ yaitu SI $630 \mathrm{mg} / \mathrm{L}$, SII $550 \mathrm{mg} / \mathrm{L}$ dan SIII 510 $\mathrm{mg} / \mathrm{L}$.

\section{DAFTAR PUSTAKA}

Adiono. 1987, Air dan Kegunaannya, USU, Medan.

Depkes RI, 1985, Pengawasan Kualitas Air Untuk Penyediaan Air Bersih Pedesaan dan Kota Keci, Jakarta.

Menkes RI, 1990, Keputusan Menteri Kesehatan RI Nomor 416/Menkes/Per/1990 tentang Syarat-syarat dan Pengawasan Kualitas Air, Depkes RI, Jakarta.

Peraturan Gubernur Bali No. 16 Tahun 2016 tentang Baku Mutu Lingkungan Hidup dan Kriteria Kerusakan Lingkungan.

$\begin{array}{ccr}\text { PERMENKES } & \text { RI } & \text { No. } \\ \text { 492/MENKES/PER/IV/2010 } & \text { tentang } \\ \text { Persyaratan Kualitas air Minum. } & \end{array}$

Peraturan Pemerintah Republik Indonesia Nomor 82 Tahun 2001 Tentang Pengelolaan Kualitas Air dan Pengendalian Pencemaran Air.

Sutrisno, Totok, 2004, Teknologi Penyediaan Air Bersih, Rineka Cipta, Jakarta. 